\title{
Land Use Directions for Land Conservation in The Rain Shadow Area of the Mount Agung- Bali
}

\author{
Dewa Made Atmaja ${ }^{1}$, I Gede Budiarta ${ }^{2}$ \\ \{made.atmaja@undiksha.ac.id¹, gede.budiarta@undiksha.ac.id²\} \\ Universitas Pendidikan Ganesha, Indonesia ${ }^{1,2}$
}

\begin{abstract}
The objectives of this study were to 1) evaluate and map the distribution of land potential on the marginal slopes of Mount Agung through the land capability evaluation mechanism; 2) evaluate and map land suitability classes through a land suitability evaluation mechanism; 3 ) identify the suitability of land use in the study area; 3 ) evaluating the suitability of land use with land capability classes and area function criteria; The long-term goal to be achieved is to increase the production of food crops for food security and reduce the rate of land degradation through conservation efforts on the slopes of Mount Agung. The method used to evaluate land capability is to classify the land into land units and assess the characteristics and land quality of each unit based on the guidelines of the Minister of Environment Regulation Number 17 of 2009. The creation of land units uses basic data in the form of Alos Avnir imagery, Landsat 7, and the digital Indonesian Earth Map by applying the working principles of Remote Sensing and Geographical Information Systems. Image processing software is ER Mapper, meanwhile for mapping and database table creation using Arc GIS. Identification of land suitability for food crops refers to the guidelines for the Regulation of the Minister of Agriculture No.79/OT.140 / 8/2013. Land use suitability is determined by comparing the land capability class with existing land use, referring to the Minister of Environment Regulation Number 17 of 2009. Land use suitability criteria are high (if the conformity is $>75 \%$ ), moderate (if the conformity is $40-75 \%$ ), and low (if the conformity is $<40 \%$ ). The criteria refer to the Regulation of the Director General of Forestry Number P.04 / VSet / 2009. The results obtained from this study are the land capacity in the research area ranging from class III to class VI scattered in each land units in accordance with the land capability map produced in this study.
\end{abstract}

Key words: potential; land; capability; suitability

\section{Introduction}

The phenomena studied and become the objectives in this study are related to land capability class, land suitability class, land use suitability, and area function determination based on existing geospatial phenomena on the northern slopes of Mount Agung-Bali.

Administrative areas of the research can be observed based on the mosaic of Indonesia's Digital Earth Map sheets 1807-413 (Kubu). The villages that are included in the scope of the research area are Datah Village, Tulamben Village, Dukuh Village, Kubu Village, Sukadana 
Village, Baturinggit Village, and Ban Village. According to Hadiwidjojo (1998), the geological condition of the research area is in the form of volcanic rocks of Mount Agung (Qva), which includes the areas of Datah, Dukuh, Tulamben, Kubu, Baturinggit, and Sukadana villages. Tuff and Buyan-Bratan and Batur (Qbb) lava deposits are found in the village area of Ban. The results of the analysis of the Bali Hydrology Map at a scale of 1: 250,000 and the Bali Soil Map (1970) show that the average groundwater content in the study area is low with a discharge of 0.1 liter / second. There is a type of soil Regosol in Datah Village, Dukuh, Tulamben, Kubu, Baturinggit, and Sukadana; and Regosol Brown in the Ban Village area, and part of the Sukadana Village. Statistic data of Karangasem Regency (2019) shows that rainfall in the northern slopes of Mount Agung is low, which is $\pm 1,300 \mathrm{~mm}$ per year with an average of $114 \mathrm{~mm}$ per month. The highest rainfall occurs in January, which is \pm $698 \mathrm{~mm}$, while the lowest rainfall occurs in May and June at $\pm 23 \mathrm{~mm}[1]$; [2].

Observing the existing land use conditions in the study area, there is a tendency that farmers have not been adaptive to the development of more relevant farming methods. Land use that does not pay attention to land potential, in addition to providing a risk of failure, can also trigger environmental degradation. Technology inputs and methods that are adaptive and capable of being alternative solutions in an effort to advance agriculture in the research area need to be developed. One of the efforts made through this research is to analyze the characteristics and quality of the land through a land evaluation approach to explore information related to land capability, land suitability and area functions in the research area. This information will then become the basis for compiling recommendations for land use to suit the existing potential of the area[3];[2].

Referring to the phenomena of the northern slopes of Mount Agung, this research feels important to be carried out as an effort to develop agricultural methods that are more adaptive and support the livelihoods of farmers in terms of capacity and land suitability. The information obtained is also an effort to anticipate the rate of land degradation caused by land use practices that are not in accordance with the criteria for land capability and area function.

\section{Method}

This study applies a spatial approach as well as an environmental approach in assessing the problems that exist in the research area. The spatial approach emphasizes the diversity of the earth's surface by examining each of its spatial aspects. The spatial aspects of the earth include the factors of location, natural conditions, and socio-cultural conditions of the community. In examining these aspects, the spatial approach pays close attention to the factors of location, distribution, interrelation, and their interactions[4].

The design used in this study is a descriptive design. Descriptive research is a research conducted with the main objective of providing an objective description or description of a situation. According to Sukmadinata (2011), descriptive research is aimed at describing or describing existing phenomena, both natural phenomena or human engineering. The phenomena described in this study are related to the condition of land capability, land use suitability, and the function of the area in the rain shadow area of the slopes of Mount Agung. The stages in this research are described as follows.

Pre-Field Work

The preliminary study is focused on identifying the units of land contained in the research area. Furthermore, the land unit map was made. Making a map of land units aims to facilitate the course of the research. The land unit provides clear boundaries for each land characteristic, especially when collecting data in the field. Based on the results of observations and analysis of the research area during the preliminary study, 12 units of land in the research area were 
identified. The software used to process satellite image data is ER Mapper, vector data is processed with MapInfo Professional, and the creation of thematic maps and geospatial database tables using ArcGIS[5].

Field Work Stage

At the fieldwork stage, the activities carried out were research sampling and direct measurement of each land unit. The research sample will be analyzed in the laboratory to determine the characteristics and quality of the land.

After Field Work

The stage after fieldwork is to analyze the various measured variables. After analyzing various parameters, then drawing conclusions related to the problems being studied.

Research sites

This research was conducted in the northern slopes of Mount Agung, Karangasem Regency, Bali Province. The research location administratively covers most of the Kubu District area. The location of the study is in the range $8^{\circ} 10^{\prime} 50$ "- $8^{\circ} 22^{\prime} 30^{\prime \prime}$ South Latitude and $115^{\circ} 28$ '30 "- $115^{\circ} 37^{\prime} 30^{\prime \prime}$ East Longitude[6].

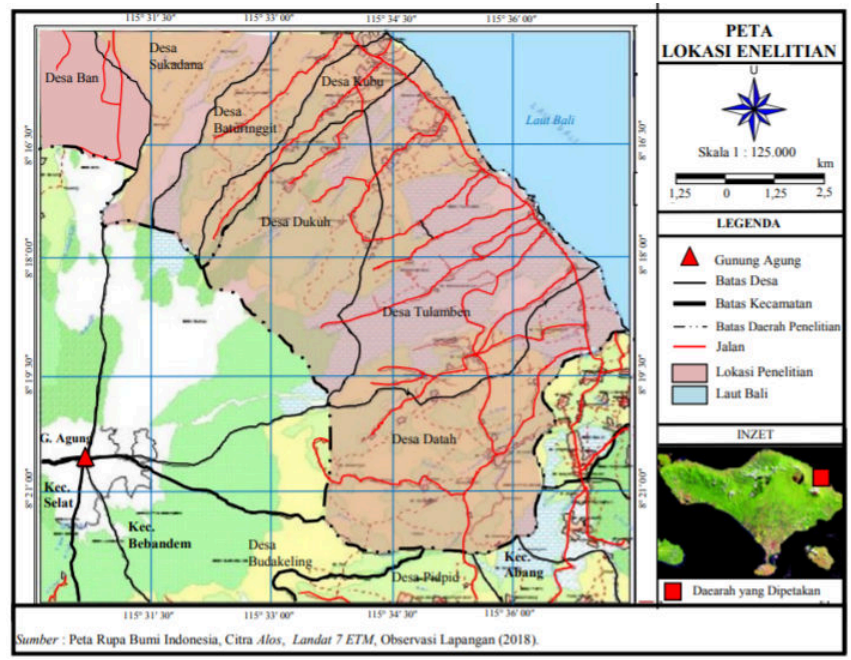

Figure 1. Research Location Map

Research Subjects and Objects

The subjects in this study were the land capability class, land use suitability, and the function of the research area. The research objects are land units that are scattered in the rainy shadow of the northern slopes of Mount Agung. The variables studied consisted of: 1). Supporting factors and limiting land capability (characteristics and land quality) such as: soil texture, surface slope, drainage, effective soil depth, erosion levels that have occurred, acid clay (clay paint), rocks above the soil surface, the threat of flooding or standing water 2). Supporting factors and limiting land suitability, such as nutrient elements[7];[8].

\section{Result and Discussion}

The data analysis technique used in this research is descriptive-qualitative. The data analysis formulas in this study are as follows. 
Determination of Land Capability Class.

The land capability class classification uses the following criteria

Table 1. Land Capability Class Criteria

\begin{tabular}{|c|c|c|c|c|c|c|c|c|}
\hline \multirow[t]{2}{*}{ Limiting Factor } & \multicolumn{8}{|c|}{ Land Capability Class } \\
\hline & I & II & III & IV & $\mathrm{V}$ & $\mathrm{VI}$ & VII & VIII \\
\hline $\begin{array}{l}\text { 1. Soil texture }(t) \\
\text { a. upper layer } \\
\text { b. lower layer }\end{array}$ & $\begin{array}{l}\mathrm{t}_{2} / \mathrm{t}_{3} \\
\mathrm{t}_{2} / \mathrm{t}_{3}\end{array}$ & $\begin{array}{l}\mathrm{t}_{1} / \mathrm{t}_{4} \\
\mathrm{t}_{1} / \mathrm{t}_{4}\end{array}$ & $\begin{array}{l}\mathrm{t}_{1} / \mathrm{t}_{4} \\
\mathrm{t}_{1} / \mathrm{t}_{4}\end{array}$ & $\begin{array}{l}(*) \\
(*)\end{array}$ & $\begin{array}{l}(*) \\
(*)\end{array}$ & $\begin{array}{l}\left({ }^{*}\right) \\
(*)\end{array}$ & $\begin{array}{l}\left({ }^{*}\right) \\
(*)\end{array}$ & $\begin{array}{l}t_{5} \\
t_{5}\end{array}$ \\
\hline 2. Slope (\%) & Lo & $1_{1}$ & $1_{2}$ & 13 & $\left({ }^{*}\right)$ & 14 & 15 & L 6 \\
\hline 3 Drainage & $\mathrm{d}_{0} / \mathrm{d}_{1}$ & $\mathrm{~d}_{2}$ & $\mathrm{~d}_{3}$ & $\mathrm{~d}_{4}$ & $\left({ }^{* *}\right)$ & $(*)$ & $(*)$ & $(*)$ \\
\hline 4. Effective depth & ko & ko & $\mathrm{k}_{1}$ & $\mathrm{k}_{2}$ & $\left({ }^{*}\right)$ & $\mathrm{K}_{3}$ & $(*)$ & $(*)$ \\
\hline 5. Erosion & eo & $\mathrm{e}_{1}$ & $\mathrm{e}_{1}$ & $\mathrm{e}_{2}$ & $(*)$ & $\mathrm{e}_{3}$ & $\mathrm{e}_{4}$ & $(*)$ \\
\hline 6. Gravel & bo & bo & bo & $\mathrm{b}_{1}$ & $\mathrm{~b}_{2}$ & $\left({ }^{*}\right)$ & $(*)$ & $\mathrm{b}_{3}$ \\
\hline 7. Flood & $\mathrm{O}_{0}$ & $\mathrm{O}_{1}$ & $\mathrm{O}_{2}$ & $\mathrm{O}_{3}$ & $\mathrm{O}_{4}$ & $(*)$ & $(*)$ & $(*)$ \\
\hline
\end{tabular}

The land capability class of the research area will be determined based on the intensity of each inhibiting / limiting factor. The land capability classes range from class I to class VIII.

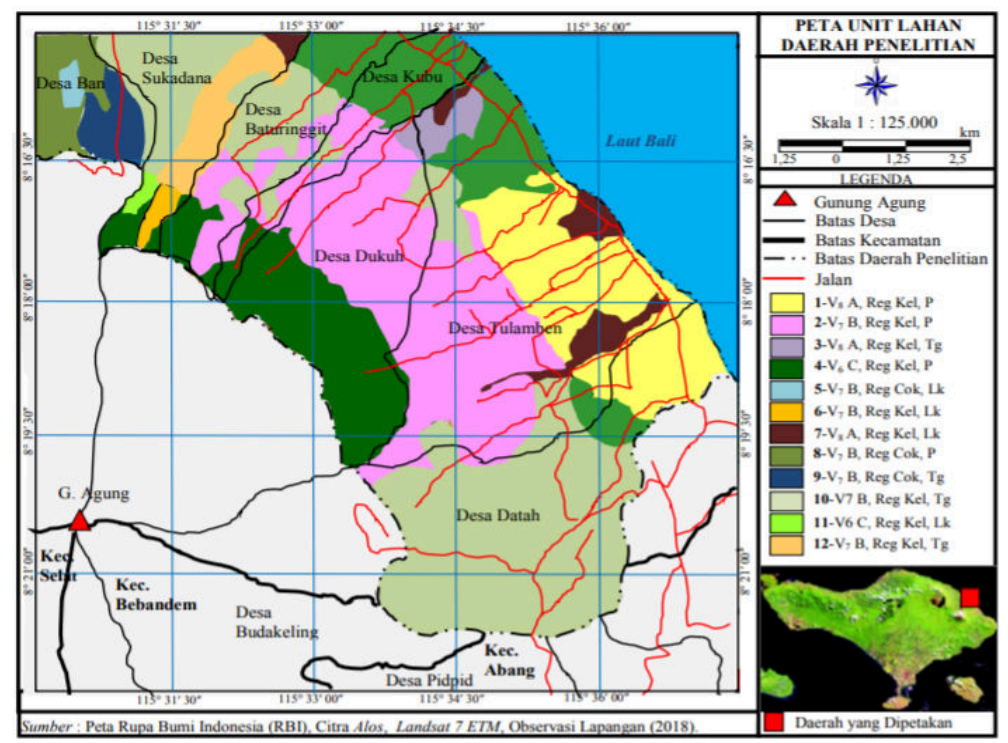

Figure 2. Research Land Unit

Determination of Land Suitability Class for Food Plants

Determination of land suitability classes for food crops follows the guidelines from the Minister of Agriculture Regulation No.79 / OT.140 / 8/2013 concerning Guidelines for Land Suitability for Food Crop Commodities. The results of this study are described in the following table [9]. 
Table 2. Land Capability in the Research Area

\begin{tabular}{|c|c|c|c|c|c|c|c|c|c|c|}
\hline \multirow[t]{2}{*}{ No } & \multirow[t]{2}{*}{ Land Unit } & \multicolumn{8}{|c|}{ Limiting Factor } & \multirow{2}{*}{$\begin{array}{l}\text { Land } \\
\text { capability } \\
\text { class }\end{array}$} \\
\hline & & $\begin{array}{l}\text { Upper } \\
\text { texture }\end{array}$ & $\begin{array}{l}\text { Lower } \\
\text { texture }\end{array}$ & Slope & $\begin{array}{c}\text { Drainag } \\
\text { e }\end{array}$ & $\begin{array}{c}\text { Kedalama } \\
\text { n efektif }\end{array}$ & $\begin{array}{c}\text { Erosi } \\
\text { on }\end{array}$ & Gravel & Flood & \\
\hline$(1)$ & (2) & (3) & (4) & (5) & $(6)$ & $(7)$ & $(8)$ & (9) & (10) & $(11)$ \\
\hline 1 & $\begin{array}{l}\text { 1/V } \mathrm{V}_{8}, \mathrm{~A}, \\
\text { Reg. Kel., } \\
\mathrm{P}\end{array}$ & $\mathrm{t}_{2}$ & $t_{2}$ & $l_{0}$ & $\mathrm{~d}_{0} / \mathrm{d}_{1}$ & $\mathrm{k}_{1}$ & $\mathrm{e}_{1}$ & $\mathrm{~b}_{0}$ & $\mathrm{O}_{0}$ & III \\
\hline 2 & $\begin{array}{l}\text { 2/V } \mathrm{V}_{7}, \mathrm{~B}, \\
\text { Reg. Kel., } \\
\text { P }\end{array}$ & $\mathrm{t}_{4}$ & $t_{5}$ & $l_{1}$ & $\mathrm{~d}_{0} / \mathrm{d}_{1}$ & $\mathrm{k}_{1}$ & $\mathrm{e}_{1}$ & $\mathrm{~b}_{0}$ & $\mathrm{O}_{0}$ & III \\
\hline 3 & $\begin{array}{l}3 / \mathrm{V}_{8}, \mathrm{~A}, \\
\text { Reg. Kel., } \\
\text { Tg }\end{array}$ & $\mathrm{t}_{4}$ & $t_{5}$ & $\mathrm{l}_{0}$ & $\mathrm{~d}_{0} / \mathrm{d}_{1}$ & $\mathrm{k}_{2}$ & $\mathrm{e}_{1}$ & $\mathrm{~b}_{1}$ & $\mathrm{O}_{0}$ & III \\
\hline 4 & $\begin{array}{c}4 / V_{6}, C, \\
\text { Reg. Kel., } \\
\text { P }\end{array}$ & $\mathrm{t}_{4}$ & $t_{5}$ & $l_{2}$ & $\mathrm{~d}_{2}$ & $\mathrm{k}_{2}$ & $\mathrm{e}_{2}$ & $\mathrm{~b}_{1}$ & $\mathrm{o}_{0}$ & IV \\
\hline 5 & $\begin{array}{c}\text { 5/V }, \text { B, } \\
\text { Reg. Cok., } \\
\text { Lk }\end{array}$ & $\mathrm{t}_{4}$ & $t_{5}$ & $l_{1}$ & $\mathrm{~d}_{2}$ & $\mathrm{k}_{3}$ & $e_{1}$ & $\mathrm{~b}_{1}$ & $\mathrm{o}_{0}$ & VI \\
\hline 6 & $\begin{array}{c}\text { 6/V } \mathrm{V}_{7}, \mathrm{~B}, \\
\text { Reg. Kel., } \\
\text { Lk }\end{array}$ & $t_{5}$ & $t_{5}$ & $l_{1}$ & $\mathrm{~d}_{0} / \mathrm{d}_{1}$ & $\mathrm{k}_{3}$ & $\mathrm{e}_{1}$ & $\mathrm{~b}_{2}$ & $\mathrm{O}_{0}$ & VI \\
\hline 7 & $\begin{array}{l}\text { 7/V } \mathrm{V}_{8}, \mathrm{~A}, \\
\text { Reg. Kel., } \\
\text { Lk }\end{array}$ & $\mathrm{t}_{5}$ & $\mathrm{t}_{5}$ & $1_{0}$ & $\mathrm{~d}_{0} / \mathrm{d}_{1}$ & $\mathrm{k}_{2}$ & $\mathrm{e}_{1}$ & $b_{1}$ & $\mathrm{o}_{0}$ & IV \\
\hline 8 & $\begin{array}{c}\text { 8/V }, \text { B, } \\
\text { Reg. Cok., } \\
\text { P }\end{array}$ & $\mathrm{t}_{2}$ & $\mathrm{t}_{4}$ & $l_{1}$ & $\mathrm{~d}_{0} / \mathrm{d}_{1}$ & $\mathrm{k}_{1}$ & $\mathrm{e}_{1}$ & $\mathrm{~b}_{0}$ & $\mathrm{O}_{0}$ & III \\
\hline 9 & $\begin{array}{c}\text { 9/V7, B, } \\
\text { Reg. Cok., } \\
\text { Tg }\end{array}$ & $t_{2}$ & $\mathrm{t}_{4}$ & $l_{1}$ & $\mathrm{~d}_{0} / \mathrm{d}_{1}$ & $\mathrm{k}_{1}$ & $\mathrm{e}_{1}$ & $\mathrm{~b}_{1}$ & $\mathrm{O}_{0}$ & IV \\
\hline 10 & $\begin{array}{c}\text { 10/V } \mathrm{V}_{7}, \mathrm{~B}, \\
\text { Reg. Kel., } \\
\text { Tg }\end{array}$ & $\mathrm{t}_{4}$ & $t_{4}$ & $l_{1}$ & $\mathrm{~d}_{0} / \mathrm{d}_{1}$ & $\mathrm{k}_{2}$ & $\mathrm{e}_{1}$ & $\mathrm{~b}_{0}$ & $\mathrm{o}_{0}$ & IV \\
\hline 11 & $\begin{array}{l}\text { 11/V6, C, } \\
\text { Reg. Kel., } \\
\text { Lk }\end{array}$ & $\mathrm{t}_{5}$ & $\mathrm{t}_{5}$ & $l_{2}$ & $\mathrm{~d}_{2}$ & $\mathrm{k}_{3}$ & $\mathrm{e}_{2}$ & $\mathrm{~b}_{2}$ & $\mathrm{O}_{0}$ & VI \\
\hline 12 & $\begin{array}{c}\text { 12/V7, B, } \\
\text { Reg. Kel., } \\
\text { Tg }\end{array}$ & $\mathbf{t}_{5}$ & $t_{5}$ & $\mathbf{l}_{2}$ & $d_{0} / d_{1}$ & $\mathbf{k}_{2}$ & $\mathbf{e}_{1}$ & $\mathbf{b}_{1}$ & $\mathbf{O}_{0}$ & IV \\
\hline
\end{tabular}

Based on Table 2, it can be seen that there are several possible land use options to be maximized in each land unit in the study area. Not only on land units that do not match land capability and use, but also on land units that are already suitable for use. Use that is appropriate needs to be intensified again as long as it is possible to do so. The land use recommendations presented in this discussion are compiled based on the existing land use 
conditions in the study area. Land capability in land unit 1, land unit 2, land unit 3 and land unit 8 is the most potential, namely class III. The land use in land unit 1, land unit 2 and land unit 8 is for smallholder plantations, but it is not intensive. While in land unit 3 the dominant land use is moor. In general, there is a match between potential and land use in these land units. However, the existing land potential should be utilized optimally. In addition to plantations (perennial crops), class III land has the potential for seasonal crop farming, as stated in the Minister of Environment Regulation Number 17 of 2009. Land units 1, land units 2, land units 3 , and land units 8 should be intensified by combining between perennials and annuals as intercrops to obtain the desired results. This is supported by Pranowo and Purwanto (2011)[6];[10], who state that planting intercrops between plantation crops is one of the efforts to optimize land for land use to increase land productivity through crop diversification.

According to Wahyuaskari (2010), class III land is suitable for all types of agricultural business with special soil preservation measures such as terracing, crop rotation and grooved planting systems. To maintain soil fertility, fertilization is needed. Meanwhile, according to USDA in Suripin (2002), class III land has a rather good capacity but agricultural business that can be carried out is rather limited. To be able to do agricultural business, investment is needed in the form of irrigation, drainage, fertilization, and erosion prevention.

Based on these alternative land uses, the recommendations for land use in class III land units in the study area are seasonal crops and plants that require land cultivation. This is intended so that the potential lands can be utilized optimally so that they can produce the expected results. In the end, optimal land use is expected to improve the welfare of farmers, especially dry land farmers on the slopes of Mount Agung[8].

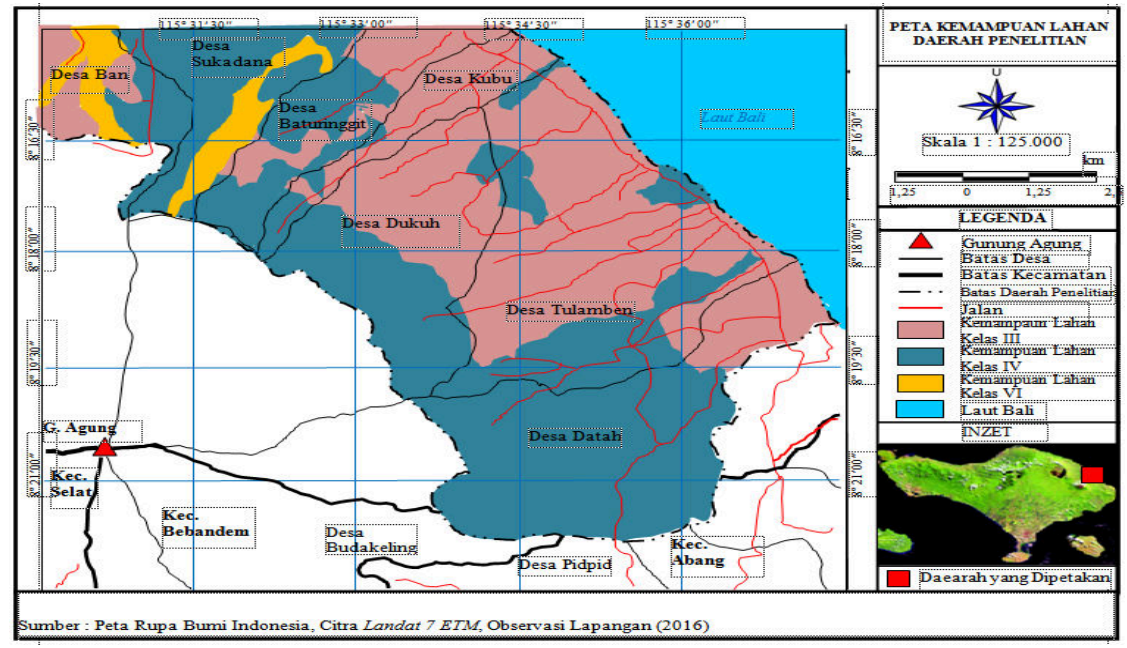

\section{Conclusion}

Figure 3. Land Capability Map

The land use recommendations presented in this discussion are compiled based on the existing land use conditions in the study area. Land capability in land unit 1, land unit 2, land unit 3 and land unit 8 is the most potential, namely class III. Alternative land uses, the recommendations for land use in class III land units in the study area are seasonal crops and plants that require land cultivation. This is intended so that the potential lands can be utilized optimally so that they can produce the expected results. 


\section{References}

[1] I. N. Manumudhita, "Penelitian Perubahan Tata Guna Tanah Di Wilayah Sekitar Danau Beratan Kabupaten Dati II Tabanan," Provinsi Bali, 2002.

[2] L. A. Nugraha, H., Wacano. D., Dipayana. A. G., Cahyadi. A., Mutaqin, B. W., "Geomorphometric characteristics of landslides in the Tinalah Watershed, Menoreh Mountains, Yogyakarta, Indonesia," Procedia Environ. Sci., vol. 28, pp. 578-586, 2015.

[3] P. Kukemilks, K., Wanger, J. F., Saks, T., Brunner, "Physically based hydrogeological and slope stability modeling of the Turaida castle mound," Landslide, 2018.

[4] Sugiyono, Metode Penelitian Kuantitatif, Kualitatif dan R\&D. Bandung: CV. Alfabeta, 2009.

[5] Esri, "How Directional Distribution (Standard Devitional Ellipse) Works - ArcGIS Pro," 2018. .

[6] T. A. Reuter, Budaya dan Masyarakat di Pegunungan Bali. Jakarta: Yayasan Obor Indonesia, 2005.

[7] P. Widayani and D. Kusuma, "Pemodelan Spasial Kerentanan Wilayah Terhadap Penyakit Leptospirosis Berbasis Ekologi," vol. 11, no. 1, pp. 71-83, 2014.

[8] J. R. Anderson, E. E. Hardy, J. T. Roach, and R. E. Witmer, A land use and land cover classification system for use remote sensor data. Washington: United Sta-tes Government Printing Office, 1976.

[9] P. Olsson, V. Galaz, and W. J. Boonstra, "Sustainability transformations : a resilience perspective," vol. 19, no. 4, 2014.

[10] J. . Jensen, Remote sensing of The Environmental Eagreen open space Resource Perspective. New Jersey-USA: Prentice Hall., 2000. 